\title{
Report on \\ XVth Executive Board Meeting \\ International Union of Forestry Research Organizations Brazil, July 1983
}

\section{Introduction}

The XVth meeting of the International Union of Forestry Research Organizations (IUFRO) Executive Board was held in Brazil from July 9-23,1983. The first part of the meeting was in Manaus, State of Amazonas, and the second part was in Curitiba, State of Parana.

IUFRO is one of the oldest scientific organizations in the world and was founded between 1890 and 1892. Since then it has promoted international cooperation in forestry research. It now has more than 500 member institutions, including more than 10000 scientists from 95 countries. IUFRO works through six subject matter Divisions which include nearly 230 research units. The work of IUFRO is conducted through correspondence, seminars, symposia and field excursions. Every five years a World Congress is organized at which technical and scientific matters are discussed in plenary, interdivisional. divisional and research unit sessions. IUFRO's six divisions are: 1 . Forest Environment and Silviculture, 2. Forest Plants and Forest Protection, 3. Forest Operations and Techniques, 4. Planning, Economics, Growth and Yield, Management and Policy, 5. Forest Products and 6. General Subjects.

The Executive Board is the governing body of IUFRO. It consists of the President. Vice-President, Past-President, IUFRO Secretary, Divisional Coordinators and eleven members from geographical regions. Current President is D. Mlinsek, Yugoslavia, Vice-President, R. Buckman, USA and Past-President, W. Liese, Federal Republic of Germany. The Executive Board meets annually. There are several committees of the Executive Board, including Finance and Planning, Program, Administration, International Relations and Public Relations.

\section{Special Coordinator for Developing Countries}

At the last IUFRO World Congress held in Kyoto, Japan in 1981, it was agreed that IUFRO activities in developing countries should be strengthened. In response to this proposal, IUFRO has recruited a Special Coordinator for Developing Countries for up to a two-year period. The Coordinator is O. Fugalli, a long-term, recentlyretired $\mathrm{FAO}$ employee. The initial program will involve the sponsoring of three planning workshops on research and technology transfer which will include the development of research action programs. These workshops will be held in Asia (March or June 1984), Africa (September 1984) and Latin America (1985). Tentative subject areas are as follows:
Asia, increasing productivity of multipurpose tree species;

Africa, fuelwood production systems and

Latin America, rehabitation of degraded lands by afforestation and reforestation

Initial funding for this initiative by IUFRO has come from the World Bank and US Aid.

Most details are available for the Asia Workshop which will likely be held in Sri Lanka. There will be four major discussion areas under the broad subject of multipurpose tree species; (a) Tree improvement and propagation, (b) Establishment and tending. (c) Enhancement and maintenance of plant productivity and (d) Silviculture and management.

\section{IUFRO in Latin America}

There is considerable concern on the part of the Executive Board that IUFRO is rather weakly represented in Latin America. Two papers were presented on this general topic, one by P. Galvao, the Latin American Regional Representative and one by W. Kauman, Deputy Coordinator, Division 5, who has had considerable experience in Latin America. The speakers pointed out that there are 50 IUFRO member institutions from 15 countries: however, 11 countries do not have any member institutions. It was emphasized that one of the main problems was the difficulty of transportation and communications; for example, the distance from Mexico to Buenos Aires exceeds 8000 $\mathrm{km}$. As one means of improving communications, it was decided to take steps to ensure that IUFRO News is published in Spanish. Indeed one issue, No. 40, already has been translated on a trial basis.

\section{International Relations}

The International Relations Committee discussed the impact of the resolutions that had been approved at the 1981 World Congress in Kyoto. These resolutions have been published in a large number of countries and it was considered that resolutions should result from the 1986 World Congress. A subcommittee was established to evaluate the impact of the 1981 resolutions and to propose guidelines and develop procedures for the 1986 Congress.

The International Relations Committee reviewed IUFRO relations with a wide variety of agencies including FAO, UNESCO, ICRAF, IUCN and the World Bank.

\section{Program 1983-86}

The Program Committee under the Chairmanship of Vice-President, R.E. Buckman, USA, reported on the status of the IUFRO program for the period 1983-86. One major activity will be an interdivisional meeting of four of the six divisions, with the theme, Human Impacts on Forests Balancing the Need of Mankind with Healthy Forests. This meeting will be held in Strasbourg in September 1984. The Program Committee is also responsible for the program of the Special Coordinator for Developing Countries and for the 1986 World Congress, which will be held in Ljubljana, Yugoslavia in September 1986. This Congress will feature a keynote speaker each morning, four sub-plenary sessions on two of the days, with the remainder of the time devoted to divisional activities. The theme selected for the Congress is Forestry Science Serving Society. In addition to various papers, the Congress will place greater emphasis on display posters than heretofore. The Congress sessions will be held from September 7 to 13 , with both pre and post Congress excursions planned for all areas of Yugoslavia.

The Board approved a number of new officers and endorsed the proposal to establish a Project Group on "Herbicides in Forestry".

\section{IUFRO Awards}

IUFRO presents three categories of recognition. The most senior is honorary membership. Three new honorary members were accepted during the year, W. Liese, Federal Republic of Germany, R. Callaham, USA and J. Pardé, France.

The second category of award is the IUFRO Scientific Achievement Awards which are presented to a limited number of young scientists at each World Congress. A Scientific Achievement Award Committee was established at the Executive Board Committee to be chaired by J.H. Cayford, Regional Representative for North America. Members of the committee are Z. Patelas, Poland, S. Ashakawa, Japan and M. Bol, The Netherlands.

The third category of award is the Distinguished Service Award, provided for service to IUFRO. The first two recipients were named in 1982: they are M. Matsui, Japan and H. Barner, Denmark.

\section{Excursions}

During the meeting a number of field excursions were made in Amazonas and Parana States. The contrast of conditions was very apparent; in Amazonas a basically unexploited natural tropical rain forest, while in Parana State much of the original forest has been exploited and major atten- 
tion is directed to reforestation and afforestation with eucalyptus, pine species and Auracaria (Brazilian-pine or Parana pine).

In Amazonas State we visited two research agencies, one the National Research Institute for the Amazon (INPA) where we saw research projects of the Tropical Silviculture Department which were devoted to the effects of commercial exploitation of the dry land rainforest on soils, water, environment and natural regeneration and reforestation trials with native and exotic species. A visit was also made to the Centre for Forest Products Research, another department of INPA. This $3 \frac{1}{2}$ year old facility has top rate equipment and research dealt with such areas as wood anatomy and properties, pulp and paper, housing and plywood and veneer. The second agency visited was the State Agriculture Experiment Station of The Brazilian Agency for Agricultural Research (EMBRAPA). Major forest research activities include agro-forestry and species trials for reforestation. Considerable emphasis is placed on technology transfer by the Agricultural Experiment Station.

In Parana State, visits were made to the Forestry School of the Federal University of Parana at Curitiba, to the South-Central Forest Research Station of the Brazilian Agency for Agricultural Research (EMBRAPA) and to a major forest industry, Industrias Klabin do Parana de Cellulose S.A.
The University of Parana is the oldest forestry school in Brazil and dates back to 1960 , with the first graduates in 1964. By 1981, there were 2238 Brazilian graduates, 669 from the University of Parana. Graduate studies commenced at the university in 1973; by 1982 there were 90 masters graduates. Currently the university maintains a well rounded program with emphasis on silviculture, forest management and wood technology, including dendrology and ecology of native species, silvicultural methods, tree breeding and genetics, gene conservation, tree seeds and nursery practise, fire protection, ecology and management, agro-forestry, timber harvesting and ergonomics, forest inventory, urban forestry and arboreculture and wildland management.

At the South-Central Forest Research Station program emphasis has been afforestation and reforestation research with attention directed to Araucaria angustifolia, pines and eucalyptus and native species. Currently $50 \%$ of effort is directed towards exotic species and $50 \%$ to native species. Research areas include genetics and tree breeding, seed technology, seedling production, plantation management, agroforestry, forest inventory, forest protection and wood technology.

The visit to Industrias Klabin do Parana was to their Monte Alegre Farm, an area of 144000 hectares. Of this area about 85000 hectares have been reforested; 8500 with Araucaria angustifolia, 8500 ha with Pinus elliottii (slash pine), 42000 hectares with Pinus taeda (loblolly pine) and 25000 with Eucalyptus. Currently about 5000 ha are planted annually with some plantations interplanted with corn. Ownership by the company of this area dates back to 1934; since then infrastructure has been constructed, a town settled and a hydro electric plant and paper mill constructed. Total mill capacity is now 1200 tons per day. Pines are managed on a 25 -year rotation; for about the last 8 years resin is extracted from the trees. In one spacing trial with slash pine, a growth rate of more than $30 \mathrm{~m}^{3}$ per hectare was obtained at a $2.00 \times 2.00 \mathrm{~m}$ spacing. Eucalyptus are clear cut at 7, 14, 21 and 30 years; with regeneration through coppicing. Mean annual increments average $30 \mathrm{~m}^{3} / \mathrm{ha} /$ year for the first rotation with a slight reduction in subsequent years. In one $E$. grandis provenance study, trees in the best provenance averaged $38.3 \mathrm{~cm}$ $\mathrm{dbh}$ and 41.31 meters at 13 years. Research is being carried out on Eucalyptus downii. Initial work has indicated an average growth of $52 \mathrm{~m}^{3} / \mathrm{ha} /$ year for a 12 -year period. The objective of the company is that the Monte Alegre property will produce 60 per cent of the wood supply required by the mill.

J.H. Cayford

Regional Representative North America

IUFRO Executive Board

\section{EDWARD \\ S. \\ FELLOWS \\ FORESTRY \& FOREST PRODUCTS CONSULTANT}

P.O. Box 354, 404 Queen St., FREDERICTON, N.B.

Registered Professional Forester (N.B.)

INDUSTRY DEVELOPMENT - FOREST PRODUCTS ECONOMIC FOREST POLICY \& ADMINISTRATION 